\title{
Investments in oil production and development in conditions of oil price stagnation
}

\author{
Sushko Olga \\ Department of Economics and Entrepreneurship, \\ Northern (Arctic) Federal University, \\ Arkhangelsk, Russia \\ o.sushko@narfu.ru
}

\author{
Plastinin Alexandr \\ Department of Management \\ Northern (Arctic) Federal University \\ Arkhangelsk, Russia \\ a.plastinin@narfu.ru
}

\author{
Saruchev Vladimir \\ general manager \\ Oil Company "VOSTOK NAO" \\ Arkhangelsk, Russia
}

\begin{abstract}
Oil price stagnation resulted in decreased investments in oil production and development. A direct correlation of a high degree was found between oil price dynamics and investments in oil production. This process will lead to a decline in oil production and reserves, causing supply and demand imbalance. It will be possible to retain the oil production level in Russia at 10.8 mln barrels per day and increase it to $565 \mathrm{mln}$ tonnes a year against the background of natural decline in oil production, caused by field depletion, due to the implementation of new projects and development of new oil deposits, northern Arctic ones among them. The northern Arctic region is considered an important center of hydrocarbon production. Oil volume in the Arctic tundra today is more than 2.5 billion tonnes. Russia prioritizes this production area on account of several processes. Field development in the northern Arctic is relevant and timely. High environmental and economic risks characteristic of the northern Arctic macroregion demands accurate systems to assess risks of the Timan-Pechora oil province development. Models of optimal transport infrastructure are developed based on the oil market current situation. The authors have selected primary factors related to the northern Timan-Pechora Province conditions. Seven groups of factors were selected, matrices for each group were developed to identify prioritized external factors. At that stage, intercorrelation coefficients were defined to exclude dependent factors from the model. Expert analysis of matrices demonstrates anticipated probability of strategic factors and the degree of their potential effect when developing deposits. Qualitative assessment of factors was made with the analytic hierarchy process method. The analysis results will enable us to identify potential capabilities and threats to oil field logistics infrastructure design.
\end{abstract}

Keywords- market development factors; oil reserves and volumes of extraction; forecasts and evaluations of market development; northern Arctic deposits; expert-analytical system

\section{THE RESEARCH ISSUE STATEMENT}

For a long time, investments in the oil and gas industry in countries with large oil and gas resources were considered the most lucrative. Among long-term projects, investments in oil extraction and refinement were attractive with their high yield and profitability against the background of positive pricing dynamics. Following the steep fall in oil prices in June 2014 and further destabilizing processes in the oil market, these investments declined. In the following period of 2015-2017, the macroeconomic situation in the oil market was also characterized by high volatility (fig. 1). After a slight increase in oil price quotations in 2015 , the declining trend continued as a result of further imbalance between supply and demand. For instance, the annual average price of Brent crude oil decreased by $47.1 \%$ (to 52 US dollars per barrel), Urals oil price fell by $47.3 \%$ (to $\$ 51$ a barrel) in 2015 . In the second half of 2015, oil price quotations were at the level of $\$ 45-50$ per barrel. A more unstable pricing dynamics was observed in 2016. Brent crude oil decreased to $\$ 27.5$ per barrel, which is its lowest over the past 12 years. Today, the oil price is at \$44-50 per barrel.

In these conditions, a large number of costly projects were postponed or stopped completely. With low oil prices, energy companies decrease operating and investment costs of oil fields exploration and production to retain output (fig. 1).

The analysis of oil production investment dynamics and the oil price trend shows a direct correlation of a high degree (0.7-0.85 correlation coefficient), i.e., the rise of energy companies' capital expenditure is closely connected with oil price growth. The correlation coefficients were defined in the reference time series which have a complex structure and seasonal, trend / cycle components, as well as random constituents (fig. 2).

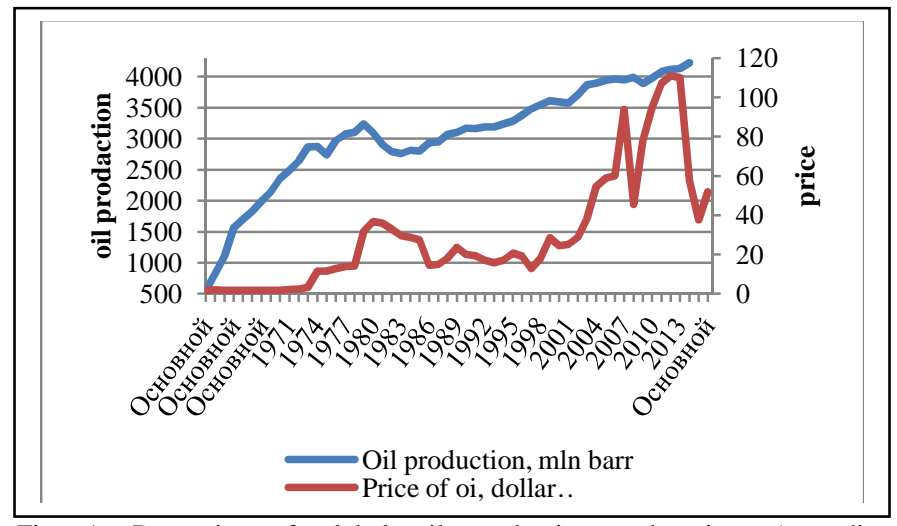

Fig. 1. Dynamics of global oil production and prices (according tohttp://oil.rftoday.ru) 


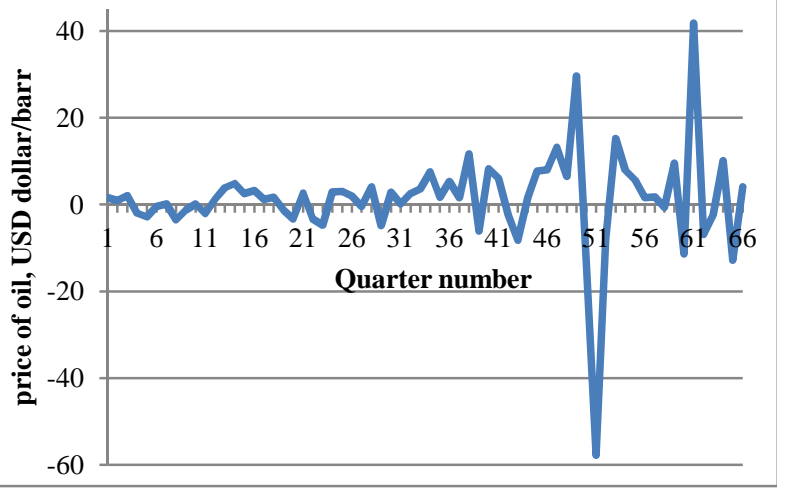

Fig. 2. Seasonal cycle dynamics of oil prices (excluding the trend)

Results of the regression and correlation analysis show that reference time series changes are unidirectional and stable. Even simple linear equations of dynamics in question have close coefficients.

After 2004, the stable growth of investments, given high oil prices and favorable development of the oil market, was connected with new projects being developed as a result of new investment opportunities (shale hydrocarbons, Brazil, Iraq, etc.), as well as their growing complexity (deepwater offshore fields, heavy oil, liquefied natural gas, etc.). In 2013 investments in geologic exploration and development grew by $11 \%$, the total amount being $\$ 690$ billion (65\% more than in 2009). A significant rise in capital expenditure took place in the Middle East (21\% in 2013), in Europe (20\%), in the AsiaPacific Region (17\%). Investment volume was somewhat lower in Latin America (grew by 14\%), CIS (11\%), Africa $(8 \%)$. The market players were planning to increase investments in geologic exploration and development with high oil prices being kept. In 2014, the market collapse and oil prices, slumping by two and a half times, threatened payback and profitability of the current projects, launching a new negative trend in oil investments (fig. 3).

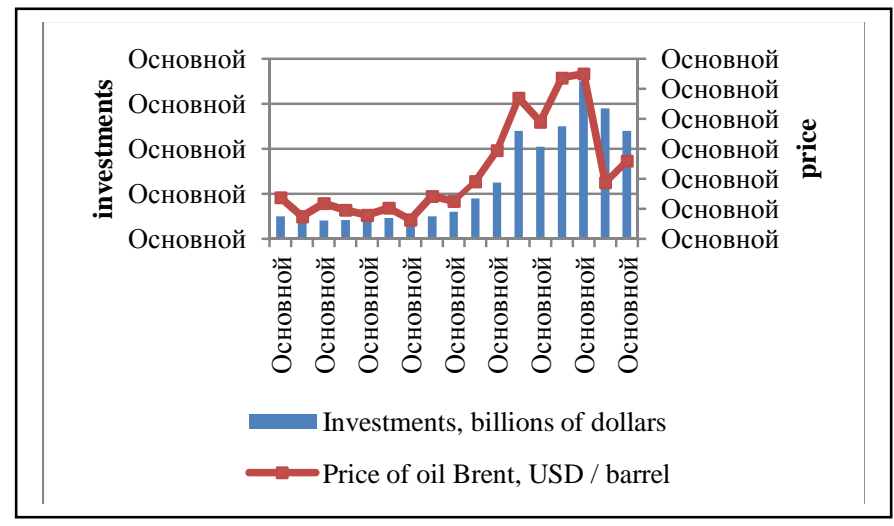

Fig. 3. Dynamics of capital expenditure on oil production and oil price trend (according tohttp://oil.rftoday.ru)

A number of oil companies have cut capital expenditure by half over the last three years. For instance, ExxonMobil cut capital expenditure to $\$ 23$ billion in 2016 (in 2013 the expenditure was $\$ 42.5$ billion). Chevron's costs associated with exploration and production reduced from 42 billion in 2013 to 25 billion in 2016. According to Goldman Sachs, an agency providing analysis, with low oil prices ( $\$ 50-55$ per barrel) investment projects worth $\$ 550$ billion or more will be put on hold. Researchers and experts, who the authors agree with, think that investment maintenance today will provide companies with high yields for the long term. Waiting for oil prices to grow, as favorable time for investments, may take a long time. Under most optimistic forecasts, oil price growth can be expected in 2018-2019. With positive pricing dynamics, large-scale projects can be expected to rise again, therefore, investments returns are possible not earlier than in ten years. The decrease in investment projects may result in oil production and supply reduction in 2030-2035. Today production volume is declining due to efforts and agreements of the market players to stabilize the market. The International Energy Agency report for May states that the global output is approximately $95 \mathrm{mln}$ barrels per day, which is 600,000 barrels lower than in 2016. In spite of the production drop oil supply exceeds demand by $800-1000,000$ barrels. Soon oil companies will have to discuss an oil production increase. According to independent forecasts given by international (OPEC, Wood Mackenzie) and Russian companies (Russian Academy of Sciences, Energy Research Institute), by 2035 oil deficit will reach 4.5 million barrels per day [1 - 2].

Thus, investment development in conditions of oil market volatility becomes an essential process to secure profitability for energy companies. At the same time, oil price dynamics should be considered as it is affected by numerous factors: economic, regulatory and political. Various factors often have opposing influence simultaneously. A significant contribution to oil price fluctuations is made by new determinants, which include discovery and introduction of innovation technologies for production, new hydrocarbons emerging as alternatives, state policy related to subsoil users, etc.

\section{PROPOSED METHODS, TOOLS}

The study of the research object was based on reports and publications released by leading scientific organizations, which develop reports on the oil market state and forecast energy development. OPEC publishes regular reports on the state of the oil market, short-term and long-term development forecasts. In recent documents OPEC identified major trends of the market development affected by various factors: low positive global economic growth, weakening of growth in developing economies, decrease in capital expenditure by global oil companies. Energy Information Administration, U.S. Department of Energy (EIA), monitors hydrocarbon resources of all types, regularly releasing statistics reports on demand and supply correlation in the oil market. According to EIA, global oil consumption will continue to increase in line with oil reserves accumulation and production decline in Russia and the Northern Sea. The American Petroleum Institute (API) conducts fundamental research of the oil industry regulation. It predicts weakening of developing economies' growth (China, Russia, Brazil), which will definitely lead to oil market oversupply. The same conclusions are found in the World Bank reports. The Bank forecasts that the U.S. and OPEC member countries will keep sustainable growth of oil production. At the same time, investments in production are expected to fall in other countries. Energy Research Institute (Russian Academy of Sciences) monitors 
energy markets and develops forecasts for the market conjuncture, the energy sectors of regions and countries, based on geopolitical and macroeconomic trends. The Institute has conducted a large-scale research project 'Global and Russian energy forecast till 2040' to analyze key drivers of world energy development [1 - 2]. The forecast predicts an average positive economic growth in the world, weakening of growth in China and BRICS countries, production movement to other developing countries in Asia and Africa, "as well as the U.S. and Russia, stimulating their economic growth and additional energy export."

The database of oil volume and cost parameters over a long period was formed for analysis. The first stage of data processing and analysis was frequency analysis of the studied oil market parameters with statistical estimation (the arithmetic mean, dispersion, mean deviation, quadratic deviation, variation coefficient, etc.). The stage of oil market parameters quantitative assessment involved different kinds of statistical analysis (correlation, dispersion, regression), economic and mathematical modeling. In the study SPSS and Statistica, software packages were applied to process data files and conduct statistical analysis.

\section{PRELIMINARY RESUlTS AND THEIR DISCUSSION}

The oil price dynamics over the last fifty years shows that recent volatility is determined not only by recent factors, but new determinants as well. Energy market conjuncture changes under the influence of fundamental factors (table 1). Hydrocarbon reserves, development of deposits, progress in geological exploration science and technology, the government's economic policy regarding subsoil use have direct influence. At the same time, supply and demand balance in the oil market is affected by the global economy development.

\section{TABLE I. FUNDAMENTAL FACTORS}

\begin{tabular}{|l|l|l|}
\hline № & $\begin{array}{l}\text { Fundamental } \\
\text { factor }\end{array}$ & Brief description \\
\hline 1 & $\begin{array}{l}\text { Demographics } \\
\text { (Table 2) }\end{array}$ & $\begin{array}{l}\text { The world population by 2040 will increase by } \\
\text { almost 2 billion people, exceeding 9 billion (an } \\
\text { average annual increase of 0.9\%). }\end{array}$ \\
\hline 2 & $\begin{array}{l}\text { Gross Domestic } \\
\text { Product (Table 3) }\end{array}$ & $\begin{array}{l}\text { World GDP by 2040 is 2.8 times higher than in } \\
2010 \text { (an annual increase of 3.5\%). }\end{array}$ \\
\hline 3 & Energy Policy & $\begin{array}{l}\text { Existing priorities of the energy policy of the } \\
\text { countries will remain. Measures will be } \\
\text { introduced to improve the energy security of } \\
\text { energy-importing countries. }\end{array}$ \\
\hline 4 & Technologies & $\begin{array}{l}\text { It is expected to gradually increase the } \\
\text { competitiveness of new technologies (shale oil), } \\
\text { as well as support the current trends in reducing } \\
\text { the energy intensity of the world's GDP. }\end{array}$ \\
\hline
\end{tabular}

Let us then turn attention to two fundamental processes, on which retaining and increasing the energy resource use level is based. According to the United Nations, the world population is going to rise by more than one fourth compared to 20132014 and exceed nine billion people (table 2). Another important factor, directly affecting oil consumption, is the gross product rise (table 3) [1 - 2].
TABLE II. FORECAST OF DEMOGRAPHIC WORLD DEVELOPMENT

\begin{tabular}{|l|c|c|c|c|c|c|}
\hline \multicolumn{1}{|c|}{ Region } & \multicolumn{2}{|c|}{$\begin{array}{c}\text { Population, } \\
\text { million people }\end{array}$} & \multicolumn{2}{c|}{$\begin{array}{c}\text { Share of able- } \\
\text { bodied } \\
\text { population, }\end{array}$} & \multicolumn{2}{c|}{$\begin{array}{l}\text { Level } \\
\text { urbanization, \% }\end{array}$} \\
\cline { 2 - 7 } & $\mathbf{2 0 1 0}$ & $\mathbf{2 0 4 0}$ & $\mathbf{2 0 1 0}$ & $\mathbf{2 0 4 0}$ & $\mathbf{2 0 1 0}$ & $\mathbf{2 0 4 0}$ \\
\hline Europe & 611 & 643 & 67 & 59 & 73 & 81 \\
\hline $\begin{array}{l}\text { North } \\
\text { America }\end{array}$ & 464 & 578 & 66 & 62 & 81 & 87 \\
\hline $\begin{array}{l}\text { Asia } \\
\text { Australia, } \\
\begin{array}{l}\text { Korea, New } \\
\text { Zealand, } \\
\text { Japan) }\end{array}\end{array}$ & 203 & 203 & 66 & 56 & 88 & 94 \\
\hline $\begin{array}{l}\text { Asia (China, } \\
\text { India) }\end{array}$ & 3632 & 4404 & 68 & 66 & 40 & 57 \\
\hline $\begin{array}{l}\text { South and } \\
\text { Central } \\
\text { America }\end{array}$ & 478 & 605 & 65 & 65 & 79 & 85 \\
\hline Near East & 216 & 332 & 65 & 68 & 68 & 74 \\
\hline Africa & 1031 & 1999 & 55 & 61 & 39 & 53 \\
\hline Europe & 6915 & 9051 & 66 & 64 & 52 & 64 \\
\hline
\end{tabular}

TABLE III. REGIONAL DYNAMICS GDP

\begin{tabular}{|l|c|c|c|c|c|c|}
\hline Region & $\mathbf{2 0 1 5}$ & $\mathbf{2 0 2 0}$ & $\mathbf{2 0 2 5}$ & $\mathbf{2 0 3 0}$ & $\mathbf{2 0 3 5}$ & $\mathbf{2 0 4 0}$ \\
\hline Europe & 17.9 & 19.8 & 21.8 & 23.8 & 25.8 & 27.9 \\
\hline North America & 20.2 & 23.6 & 26.9 & 30.0 & 32.9 & 35.6 \\
\hline $\begin{array}{l}\text { Asia (Australia, } \\
\text { Korea, New Zealand, } \\
\text { Japan) }\end{array}$ & 7.5 & 8.2 & 9.0 & 9.6 & 10.2 & 10.7 \\
\hline Asia (China, India) & 26.5 & 36.1 & 47.6 & 61.3 & 77.5 & 96.2 \\
\hline $\begin{array}{l}\text { South and Central } \\
\text { America }\end{array}$ & 5.7 & 6.9 & 8.1 & 9.4 & 10.8 & 12.2 \\
\hline Near East & 3.5 & 4.2 & 5.1 & 5.9 & 6.9 & 7.9 \\
\hline Africa & 3.7 & 4.8 & 6.1 & 7.7 & 9.6 & 11.9 \\
\hline World & 88.7 & 108.0 & 129.7 & 153.7 & 180.5 & 209.8 \\
\hline
\end{tabular}

Taking into account the given fundamental factors forecast, primary energy consumption in the world has a positive trend, rising annually by $1.3-1.5 \%$.

Today new determinants of the oil market development are global political and military processes. Current events in Iran demonstrate stabilization enabling the country to enter global oil and gas markets. The oil production renewal in Iran with shale oil recovery rising will increase supply with sharp price movements. Another new factor is escalating tensions between Russia and the EU, which affected their energy relations and hydrocarbon supply destinations. The new energy policy of the EU will facilitate shifts in the European energy balance. Other new factors in global energy development include the Asian economic growth. In spite of coal production maximization in China and India, they will not meet their domestic energy needs which will change the global energy market volume. These processes will unavoidably affect Russia, posing additional risks and opening new opportunities for its export. Agreements between OPEC and non-OPEC member countries to limit oil output temporarily, as well as the Federal Reserve, the central bank of the United States, plans have become new determinants of the oil market development [4]. In 2014 global oil production increased by $1.8 \%$, the highest growth rate over the last ten years. In 19201970 global oil production grew steadily (almost doubled 
every ten years), whereas from 1980, the growth rate slowed, several years later some decline was observed (table 4) [1-3].

TABLE IV. FORECAST OF OIL PRODUCTION IN THE REGIONAL CONTEXT

\begin{tabular}{|l|c|c|c|c|c|}
\hline Region & $\mathbf{2 0 2 0}$ & $\mathbf{2 0 2 5}$ & $\mathbf{2 0 3 0}$ & $\mathbf{2 0 3 5}$ & $\mathbf{2 0 4 0}$ \\
\hline Europe & 163 & 155 & 140 & 133 & 132 \\
\hline North America & 862 & 951 & 962 & 956 & 956 \\
\hline Asia and & 387 & 381 & 363 & 343 & 341 \\
\hline $\begin{array}{l}\text { South } \begin{array}{l}\text { Central } \\
\text { America }\end{array} \\
\text { Near East }\end{array}$ & 515 & 522 & 533 & 541 \\
\hline Africa & 1466 & 1519 & 1643 & 1715 & 1755 \\
\hline World & 4487 & 516 & 521 & 543 & 527 \\
\hline
\end{tabular}

In line with the global oil production growth oil reserves are rising. Since 2014-2015Saudi Arabia oil reserves have increased slightly (1.1 billion barrels). OPEC countries continue to control the largest share of global reserves, which is $71.6 \%$ of the global volume [4]. Today global reserves total approximately 1660 billion barrels. More than $18 \%$ of the global oil reserves are found in Venezuela (298 billion barrels). From 2000 the country increased its oil reserves fourfold, mainly due to heavy and extra heavy oil. Saudi Arabia holds large oil reserves (around 268 billion barrels or $16 \%$ of the world's reserves). Russia and the U. S. have average proven oil reserves ( 80 billion barrels, $5 \%$ of the global reserves, and 36 billion barrels, $2 \%$ of the global reserves) [5]. Despite decreasing oil prices, the US increases oil production due to shale deposit exploration and rising development of existing fields. Among OPEC countries Iraq demonstrates the highest oil production volume, as the country faces financial difficulties, fighting ISIS.

Over the time of 1974-2017 the Russian oil production dynamics show long periods of growth and decline. The longterm oil production growth was followed by the fall in 1987 , which lasted ten years. Since 2000 Russia has had a positive oil production trajectory (fig. 4), though the record level achieved by the RSFSR in 1987 (569.5 million tonnes) has not been achieved.

Given the results of petroleum refining at the internal market, the Russian export totaled 255-260 million tonnes in 2016. According to VYGON Consulting forecasts, in 2017 the Russian oil export to foreign markets will be 270-275 million tonnes [6-7]. The biggest part of Russian oil is exported to Europe. The Russian export oil flow to Europe will lose some market share to mid-range suppliers with cheaper resources. The Russian oil export to Europe will start to fall in 2020. By 2040, the European consumption of Russian oil will total 14$15 \%$, which is two times lower than at present [1-3].

Oil production needs should be met not only by oil production, but by oil reserves growth as well. In 2015-20166 global oil reserves were 1657-1700 billion barrels. Numerous studies state that these reserves are diminishing significantly. Existing and proven oil reserves can meet the global human needs during the next thirty years. The largest oil reserves are in Venezuela (298 billion barrels) and Saudi Arabia (268 billion barrels). The Russian oil reserves are 80 billion barrels ( $5 \%$ of the global oil reserves). As mentioned above, factor reduction of oil prices causes the deceleration of investment projects, cancellation of plans to increase deposit capacity and production. Natural reduction of oil production due to oil field depletion and rising oil demand becomes more topical for many oil producing countries. Azerbaijan, Mexico, Equatorial Guinea, Sudan, South Sudan are expected to face the problem of oil production decline [8-9]. Over a long period of time, Russia has been diminishing its oil reserves. Oil stock quality deteriorates, as the share of tight oil resources increased to $55 \%$. Most oil reserves have a large extent of field depletion (70-80\%). It mainly refers to the European part of the country, producing one third of Russian oil and gas (around 155 million tonnes): the Urals and Volga Region, the North Caucasus, the Timan-Pechora Province. Oil production falls in Western Siberia too, even with the latest large field development start. The Russian oil production rise in 20112016 was based on projects in the east of the country (the Sakha Republic, the Irkutsk Region, the Sakhalin shelf), in the north of Western Siberia (Yamal Nenets Autonomous Area), offshore projects (table 5). Oil production in the Volga-Ural and Timan-Pechora basins actively involves technologies of production stimulation. Smaller fields are used to compensate for a production decline in large and medium deposits in the region.

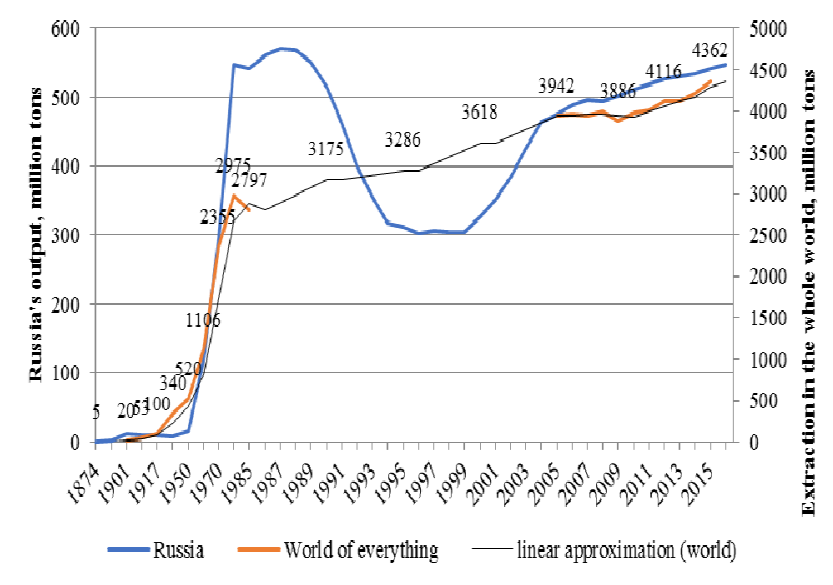

Fig. 4. Dynamics of oil production in Russia and the world as a whole

TABLE V. REGIONAL OIL EXTRACTION IN RUSSIA

\begin{tabular}{|l|l|l|l|l|l|l|l|}
\hline Region & $\mathbf{2 0 0 9}$ & $\mathbf{2 0 1 0}$ & $\mathbf{2 0 1 1}$ & $\mathbf{2 0 1 2}$ & $\mathbf{2 0 1 4}$ & $\mathbf{2 0 1 5}$ & $\mathbf{2 0 1 6}$ \\
\hline $\begin{array}{l}\text { European } \\
\text { Russia }\end{array}$ & 149.2 & 152.3 & 152.7 & 151.6 & 155 & 158 & 154 \\
\cline { 1 - 1 } $\begin{array}{l}\text { Western } \\
\text { Siberia }\end{array}$ & 322.1 & 318.2 & 316.3 & 317.2 & 313 & 312 & 322 \\
\hline $\begin{array}{l}\text { Eastern } \\
\text { Siberia }\end{array}$ & 7.5 & 19.7 & 27.2 & 35.1 & 41.1 & 63.5 & 68.0 \\
\cline { 1 - 6 } Far East & 15.4 & 14.8 & 15.2 & 14.2 & 12.4 & & \\
\hline
\end{tabular}

Retaining the Russian oil production rate at 10.8 million barrels per day and its increase to 565 million tonnes per year will be possible due to investment project implementation and the development of new oil fields. It is the state's direct interest as it is the natural resources owner. According to forecasts of the Natural Resources Ministry, Russia will be able to increase its oil reserves by 13-15 billion tonnes [10]. Oil production can be maintained with more accessible sources, as well as with deposits6 having low permeability, 
which include the northern Arctic reserves. The northern Arctic region is considered an essential hydrocarbon production basin. Development of deposits in the north needs large investments in infrastructure improvement and development of transport routes. Oil reserves in the Arctic tundra rose by 2.5 billion tonnes according to the American experts' estimates [9]. It is underlined that the northern Arctic oil production region becomes a priority due to several processes. The process of high depletion at existing oil deposits and growth of tight reserves (their share being more than $60 \%$ ) decrease the oil recovery factor, which does not exceed $30 \%$. Oil production increasing needs investments and more expensive innovation technologies. It is challenging for Russian oil producers to increase investments due to ongoing sanctions and constraints, limiting Russian access to capital markets. In 2015 investments in oil production fell by 9 billion RUB. Investments in oil pipeline transportation dropped by 15 billion RUB. Most Russian oil companies use international ready-made equipment and technologies. Access to these technologies and equipment was banned in 2015, when the United States imposed strict limitations, preventing American companies from participation in oil production in Russia (deepwater regions, the Arctic shelf). As a result the first exploration drilling by Rosneft in the Kara Sea was stopped. The project was conducted together with the American ExxonMobil. Despite growing tensions in the Russian oil market, the country's oil producers extend their activities in the Timan-Pechora oil province, which is located in the Nenets Autonomous Area and the Komi Republic (350 thousand $\mathrm{m}^{2}$ ). At present, the Timan-Pechora Province contains more than 180 deposits, 136 oil deposits, 4 gas deposits, 2 deposits have oil and gas, 13 ones have oil and gas condensate, 12 - gas condensate, 16 - gas. Lukoil and Rosneft companies have been developing the Timan-Pechora oil and gas province since 1998 and 2003 (table 6).

TABLE VI. OIL EXTRACTION IN RUSSIA AND TIMANOPECHORA DEPOSIT «LUKOIL»

\begin{tabular}{|c|c|c|c|c|c|}
\hline Year & $\begin{array}{c}\text { Overall, } \\
\text { million tons }\end{array}$ & $\begin{array}{c}\text { Growth } \\
\text { tempos } \\
\text { to the } \\
\text { previous } \\
\text { period } \\
\text { \% }\end{array}$ & $\begin{array}{c}\text { Timan- } \\
\text { Pechora, } \\
\text { \% }\end{array}$ & $\begin{array}{c}\text { Million } \\
\text { tons }\end{array}$ & $\begin{array}{c}\text { Growth } \\
\text { tempos } \\
\text { to the } \\
\text { previous } \\
\text { period, } \\
\text { \% }\end{array}$ \\
\hline 1998 & 67600 & & 0 & 0 & \\
\hline 1999 & 79800 & 118.0 & 10.6 & 10.4 & 102.9 \\
\hline 2000 & 77741 & 97.4 & 13.7 & 10.7 & 98.1 \\
\hline 2001 & 78322 & 100.7 & & 10.5 & 100.0 \\
\hline 2002 & 79800 & 101.9 & & 10.5 & 102.9 \\
\hline 2003 & 81500 & 102.1 & 13.7 & 10.8 & 108.6 \\
\hline 2004 & 86200 & 105.8 & 13.6 & 11.73 & 106.4 \\
\hline 2005 & 90158 & 104.6 & 13.8 & 12.48 & 109.0 \\
\hline 2006 & 95235 & 105.6 & 14.3 & 13.60 & 107.1 \\
\hline 2007 & 96645 & 101.5 & 15.1 & 14.57 & 114.5 \\
\hline 2008 & 95240 & 98.5 & 17.5 & 16.68 & 129.9 \\
\hline 2009 & 97615 & 102.5 & 22.2 & 21.66 & 97.7 \\
\hline 2010 & 95922 & 98.3 & 22.1 & 21.17 & 82.9 \\
\hline 2011 & 90917 & 94.8 & 19.3 & 17.55 & 89.1 \\
\hline 2012 & 89856 & 98.8 & 17.4 & 15.63 & 100.0 \\
\hline 2013 & 89856 & 100.0 & 17.4 & 15.63 & 102.0 \\
\hline 2014 & 97208 & 108.2 & 16.4 & 15.94 & 170.6 \\
\hline 2015 & 100700 & 103.6 & 27.0 & 27.19 & 102.9 \\
\hline & & & & & \\
\hline
\end{tabular}

Further development and implementation of new projects depend on transport infrastructure enhancement. The development of the northern Arctic deposits is relevant and timely. It requires accurate assessment methods and models, streamlining transport infrastructure and taking into account the current situation at the oil market. At present primary factors are being selected for the North Timan-Pechora Province, their assessment by experts is based on the importance and influence on final results of the study. At the current work stage the main task is to develop the integrated environmental and economic model to conduct systemic analysis to evaluate and forecast basic factors in the territory's oil resources development. Seven groups of factors were selected (table 7) [11]. A matrix was made for each group to identify prioritized external factors. At that stage intercorrelation coefficients were defined to exclude dependent factors from the model, as independence of factors is an important condition for the model development. Expert analysis of matrices demonstrates anticipated probability of strategic factors and the degree of their potential effect when developing deposits. The analysis results will enable us to identify potential possibilities and threats. It is necessary to design effective routes for oil transportation. The next stage of the research involves factor analysis to select factors necessary to develop models. These models are part of an expert system to develop oil transportation infrastructure in the northern Arctic Region.

TABLE VII. FACTORS OF THE INTEGRATED MODEL [11]

\begin{tabular}{|c|c|}
\hline Groups of factors & Kinds \\
\hline $\begin{array}{l}\text { Environmental } \\
\text { factors }\end{array}$ & $\begin{array}{l}\text { Specially protected natural areas. } \\
\text { Water protection zones of watercourses and } \\
\text { reservoirs. } \\
\text { Areas of increased bioproductivity } \\
\text {.Degree of pollution of the natural environment. }\end{array}$ \\
\hline Climatic factors & $\begin{array}{l}\text { Wind regime. } \\
\text { Temperature regime. } \\
\text { Precipitation mode. } \\
\text { Dangerous hydrometeorological phenomena. }\end{array}$ \\
\hline Hydrological factors & $\begin{array}{l}\text { Wetlands of the territory. } \\
\text { Transitions through waterways and reservoirs. } \\
\text { Level mode. } \\
\text { Ice regime. }\end{array}$ \\
\hline $\begin{array}{l}\text { Physicogeographical } \\
\text { and geological } \\
\text { factors }\end{array}$ & $\begin{array}{l}\text { Relief. } \\
\text { Soil conditions and soils. } \\
\text { Resource potential. } \\
\text { Cryogenic processes. } \\
\text { Exogenic processes. } \\
\text { Seismicity. } \\
\end{array}$ \\
\hline Capital expenditures & $\begin{array}{l}\text { Cost of equipment } \\
\text { Cost of construction and installation works and } \\
\text { services * } \\
\text { Fees for imported equipment } * \\
\text { Cost of credit resources * } \\
\text { Access to sources of raw materials }\end{array}$ \\
\hline Current expenses & $\begin{array}{l}\text { Tariffs for electricity for transportation } * \\
\text { Freight cost } * \\
\text { Cost of main pipeline services } * \\
\text { The amount of excises, customs duties and taxes }\end{array}$ \\
\hline Income & $\begin{array}{l}\text { The price of oil } \\
\text { Taxes, fees to off-budget funds } \\
\text { Exchange rate }\end{array}$ \\
\hline
\end{tabular}

Currently the authors are working with the algorithm to define factor influence, using the integral method. The integrated model of deposit transport infrastructure 
development will enable us to predict mean values for the most significant factors, which define oil transportation logistics when developing oil deposits. Quantitative assessment of factor influence was made with the analytic hierarchy process. As a result, the weight coefficients were established, their sum equaling one unit (or 100\%) [11]. Due to differences in factor groups' size, the weight coefficients were adjusted to a common scale and multiplied by intergroup weight coefficients (fig. 6) [11].

The analysis demonstrates more than $65 \%$ parity of economic factors (operating and capital costs, incomes) over environmental factors, which is explained by their high uncertainty and significant risk, affecting the project effectiveness [11]. Financial and economic factors, fluctuating widely, depending on the market conjuncture, the geopolitical situation, legislation changes, and other conditions, can largely affect revenue performance and profitability of projects. exploitation, development of algorithms to identify effective routes for oil transportation. Qualitative analysis of factors demonstrated the significance of economic factors, the cumulative weight coefficient of which will amount to $65.5 \%$. At the current stage, the main target is to develop the integrated environmental and economic model to conduct systemic analysis to evaluate and forecast major factors in the territory's oil resources development. The conducted research results and conclusions will be applied as the theoretic and methodological basis for the development of new oil deposits, taking into account relevant factors.

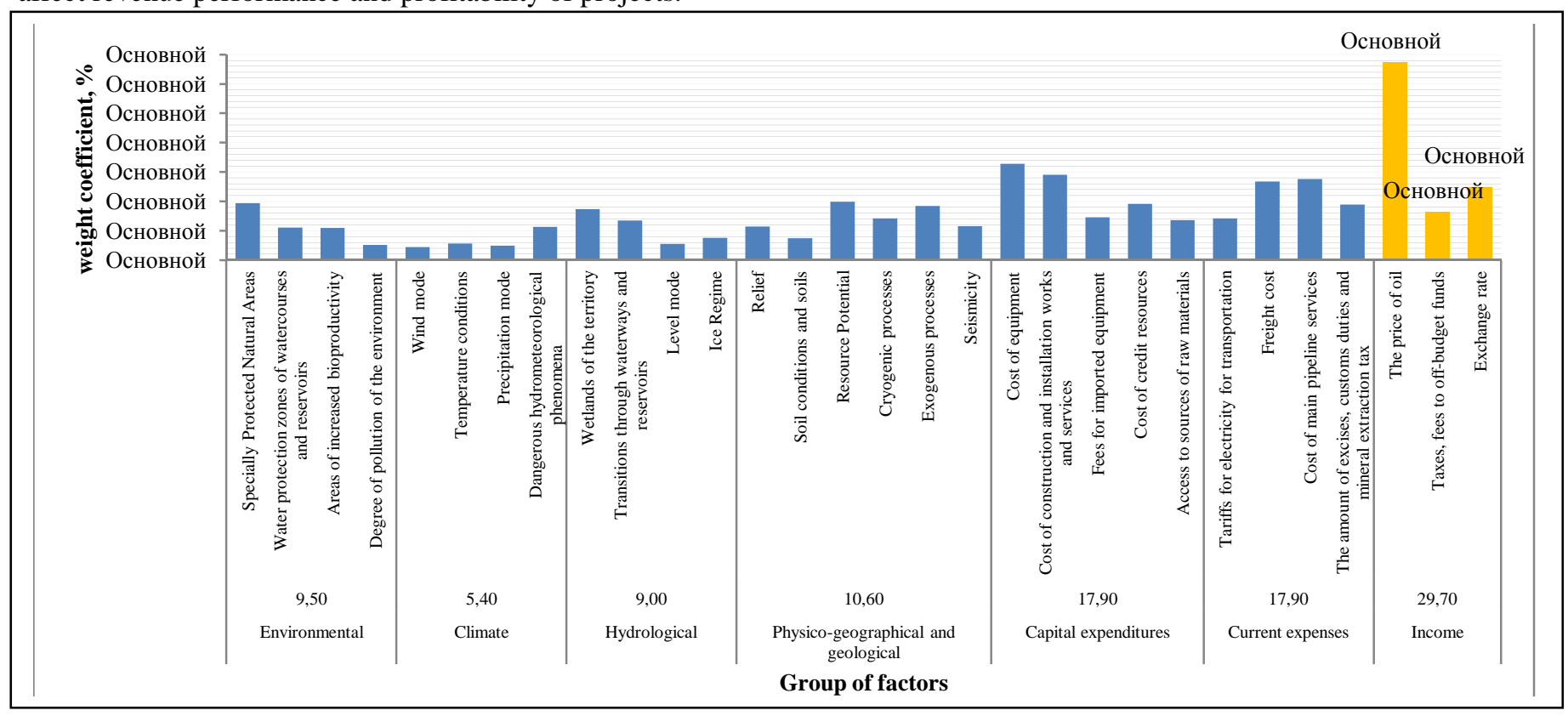

Fig. 5 INTERGROUP WEIGHT COEFFICIENTS OF FACTORS [11]

\section{CONCLUSIONS AND PLANS FOR RESEARCH OF THE PROBLEM}

Thus, the global oil market is currently dealing with the economic crisis. Over the period to 2040, it is expected to be transformed significantly. The market changes will be affected by rising self-sufficiency of North America due to unconventional oil and gas resources, growing energy demand in developing Asian countries. Energy resources import to Europe will increase slightly, which fact changes the oil and gas import structure. In these conditions, oil market development in Russia involves maintaining oil reserves and production, because over a long time, Russian oil reserves have been declining. Despite growing tensions in the oil market, Russian oil producers extend their activities in the Timan-Pechora oil province, which is located in the Nenets Autonomous Area and the Komi Republic. Further advancement and implementation of new projects to enhance transport infrastructure in the Northern macroregion, given its high environmental and economic risks, requires improved methods to assess environmental and economic risks of future

\section{References}

[1] Energy outlook peace and Russia until 2040, ERI RAS 2013 [Electronic resource]; URL: https://www.eriras.ru/files/prognoz-2040.pdf (accessed 20. 50.2017).

[2] Resource-innovative development of the Russian economy / Under the editorship of A. M. Mastepanov, N. Komkova I. and others, M.: Institute of computer science, 2013, $736 \mathrm{p}$.

[3] Braginsky O. B. oil Prices: history, forecast, impact on the economy; ROS. chem. well (J. ROS. chem. Ob-VA im. D. I. Mendeleev), LII, 6, pp. 25-36, 2008.

[4] «The decision of OPEC can raise the price of oil to \$60», OIL. Expert [Electronic resource], URL: http://www.oilexp.ru/news/reshenie-opekmozhet-podnyat-cenu-na-neft-do-60/111339

[5] FAOstat [Electronic resource], URL: http://faostat.fao.org/ (accessed 20.06.2017).

[6] R.M. Melnikov «The Influence of changes in oil prices on macroeconomic indicators of the Russian economy», Economic Issues, 1, pp. 17-23, 2010.

[7] K.M. Lui and T.L. Chong Do «Technical Analysts Outperform Novice Traders: Experimental Evidence», Economics Bulletin, 33(4), pp. 3080-3087, 2013. 
[8] W.C. Labys «Recent Developments in Commodity Modeling», The World Bank: Working Papers, 1998, October, 358 p.

[9] A. A. Konoplyanik World oil market: evolution of the pricing mechanism [Electronic resource]

URL: http://www.konoplyanik.ru/ru/publications

[10] A.O. Goryachev «Forecasting of the world markets development of liquid fuels until 2040 by using an optimization model», Problems of
Economics and management of oil and gas complex, vol. 2, pp. $34-41$, 2014.

[11] M.G. Gubaidullin, V.B. Korobov, V.V. Sarychev «Analysis of environmental and natural factors affecting the rationale for locating transport infrastructure facilities in the Russian Arctic», Neftegaz, vol. 3, pp. $87-92,2017$ 